\title{
The relation between pain perceived by the patients hospitalized in the algology clinic and their sleep and quality of life
}

\author{
Ağrı kliniğinde yatan hastaların algzladiğz ağrn ile \\ uyku ve yaşam kalitesi arasindaki ilişki
}

\author{
Gülay YILDIRIM, ${ }^{1}$ Şükran ERTEKIN PINAR, ${ }^{2}$ Cevdet DÜGER, ${ }^{3}$ Saliha ALTIPARMAK, ${ }^{4}$ \\ Sinan GÜRSOY, ${ }^{3}$ Caner MIMAROĞLU3
}

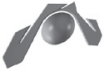

\section{Summary}

Objectives: The aim of the present study was to determine the effects of perceived pain on quality of sleep and life in patients hospitalized in a pain clinic.

Methods: Population of the present descriptive study composed of patients ( $>18$ years old) treated as inpatients in the algology clinic of a university located at the city center of Sivas, who consented to participate in the study (122 patients). Data were collected through Personal Information Form, Visual Analog Scale (VAS), Pittsburg Sleep Quality Index (PSQI) and Short Form 36. Data were analyzed using independent t-test, Mann Whitney U test, Kruskal Wallis test and Pearson correlation test. Statistical significance level was set at $\mathrm{p}<0.05$.

Results: A moderate negative correlation was found between VAS and three dimensions of SF-36, namely Physical Functioning, Role-Physical and Role-Emotional. VAS was weakly and negatively correlated to Vitality and Mental Health. There was a good linear correlation between VAS and quality of life (QoL), pain score while there was a moderate linear correlation between VAS and the total sleep score. It was found that quality of life was not statistically significantly correlated to General Health and Social Functioning.

Conclusion: There is a relationship between pain, sleep quality and quality of life. Quality of sleep and life was found to decrease as the level of pain increased, and quality of life was affected negatively when the quality of sleep was poor. Applications towards resolving pain would have a positive effect on the quality of sleep and life.
\end{abstract}

Key words: Pain; pain patients; sleep quality; quality of life.

\begin{abstract}
Özet
Amaçઃ Ağrı kliniğinde yatan hastaların algıladığı ă̆rının uyku ve yaşam kalitesi üzerine etkisini belirlemek.

Gereç ve Yöntem: Sivas'ta bir üniversite hastanesinin ă̆rı kliniğinde yatarak tedavi gören, çalısmaya katılmayı kabul eden 122 basta örneklemi oluşturmuştur. Veriler Kişisel Bilgi Formu, Visüel Analog Skala (VAS), Pittsburg Uyku Kalitesi Ölçeği (PUKÖ) ve Kısa Form 36 (SF-36) ile toplanmıştır. Verilerin değerlendirilmesinde bağımsız gruplarda t-testi, Mann-Whitney U testi, Kruskal-Wallis testi ve pearson korelasyon analizi kullanılmıştır. Anlamlilı düzeyi $p<0.05$ olarak alınmıştır.

Bulgular: VAS ile yaşam kalitesi alanları olan fiziksel işlevsellik, fiziksel rol güçlüğü ve emosyonel rol güçlüğ̈̈ arasinda orta derecede ters yönde bir ilişki belirlendi. VAS ile vitalite ve rubsal sağlık arasinda zayıf derecede ters yönde bir ilişki belirlendi. VAS ve toplam uyku skoru arasında orta derecede doğrusal bir korelasyon var iken VAS ve yaşam kalitesi ağrı alan puanı arasında iyi bir korelasyon saptandı. Uyku kalitesi ile yaşam kalitesi alt alanları olan genel sağltk ve sosyal fonksiyon alanlarında ise istatistiksel olarak anlamlı bir ilişki belirlenemedi.

Sonuç: Ağrı, uyku kalitesi ve yaşam kalitesi arasında ilişki vardır. Ağr düzeyi arttıkça uyku ve yaşam kalitesinin olumsuz olarak etkilendiği, uyku kalitesi azaldığında da yaşam kalitesinin olumsuz yönde etkilendiği saptanmıştır. Araştırma bulgularına göre hastaların uyku kalitesinin kötü olduğu belirlenmiştir. Bunun için de ağrıyı gidermeye yönelik uygulamalar, uyku ve yaşam kalitesi üzerinde olumlu bir etkiye sabip olacaktır.
\end{abstract}

Anahtar sözcükler: Ağrı; ağrısı olan hastalar; uyku kalitesi; yaşam kalitesi.

Presented at the 2nd International and 6th National Psychiatric Nursing Congress as a poster presentation (0ctober 4-7, 2012, Erzurum, Turkey).

'Department of Deontology and Ethics, Cumhuriyet University Faculty of Medicine, Sivas, Turkey;

${ }^{2}$ Department of Midwifery, Cumhuriyet University Faculty of Health Sciences, Sivas, Turkey;

${ }^{3}$ Department of Anesthesiology, Cumhuriyet University Faculty of Medicine, Sivas, Turkey;

${ }^{4}$ Department of Midwifery, Celal Bayar University Faculty of Health Sciences, Manisa, Turkey

'Cumhuriyet Üniversitesi Tıp Fakültesi, Tıp Tarihi ve Etik Anabilim Dalı, Sivas;

${ }^{2}$ Cumhuriyet Üniversitesi Sağlık Bilimleri Fakültesi, Ebelik Bölümü, Sivas;

${ }^{3}$ Cumhuriyet Üniversitesi Tıp Fakültesi, Anesteziyoloji ve Reanimasyon Bölümü, Sivas;

${ }^{4}$ Celal Bayar Üniversitesi Sağlık Bilimleri Fakültesi, Ebelik Bölümü, Manisa

Submitted (Başvuru tarihi) 12.12.2013 Accepted after revision (Düzeltme sonrası kabul tarihi) 01.07.2014

Correspondence (İletişim): Dr. Şükran Ertekin Pınar. Cumhuriyet Üniversitesi Sağlık Bilimleri Fakültesi, Ebelik Bölümü, 58140 Sivas, Turkey. Tel: +90 - 346 - 2191010 / 1558 e-mail (e-posta): spinar75@gmail.com 


\section{Introduction}

According to the International Association for the Study of Pain (IASP), pain is an unpleasant sensory and emotional experience associated with actual or potential tissue damage, or described in terms of such damage. ${ }^{[1]}$ Pain, protecting the organism from further physiological or possible dangers, is a multi-dimensional, complex and unpleasant feeling influenced by past experiences. ${ }^{[2]}$ Causing stress and anxiety, pain may lead to a poor sleep and low quality of life by disturbing productivity, relationships, well-being, functional capacity and ability of self-caring and fulfilling family, social and occupational roles of a person. ${ }^{[3]}$

Quality of sleep is defined as one's feeling robust, fit and ready for a new day. Sleep quality is a measure which includes sleep latency, duration of sleep, number of awakenings per night, depth of sleep and resting. ${ }^{[4]}$ Sleep is an important criterion for health and well-being. ${ }^{[5]}$ In the literature, $50-70 \%$ of those experiencing pain has sleep problems and it is reported that there is a positive correlation between pain and sleep problems. ${ }^{[6-8]}$ It is also stated in experimental studies conducted on animals and human beings that there is a positive correlation between sleep disorder and pain. ${ }^{[9]}$ Pain causes an individual to experience difficulties with falling asleep and maintaining sleep, increases sensitivity to pain and decreases ability cope with pain. ${ }^{[6,10]}$

Along with affecting sleep quality, pain may increase use of healthcare services and treatment expenses and decrease productivity and labour force participation. [5,11] World Heath Organization describes quality of life as the patient's perception of his/her position in life in the context of the culture and value systems in which he/she lives and in relation to his/her goals, expectations, standards and concerns. ${ }^{[12]}$

Based on the perceptive and affective centers of the brain, perception and definition of pain and behavioural responses to pain differ among individuals. $[1,13,14]$ Response of an individual to pain changes based on his/her sensory perception, psychological status, ability to cope with pain, attitude of his/her family and how the he/she interprets pain. ${ }^{[2]}$ For this reason, it is necessary to interview with such patients in detail, take an adequate history, ensure continu- ous monitoring, use appropriate methods for pain evaluation and take into consideration verbalization of pain. ${ }^{[3,13]}$ In this context, it is important to determine the impact of pain on the quality of sleep and life and plan necessary care, treatment and discharge training.

As insufficient pain management sometimes causes undesired consequences such as decreased functional status and increased fatique and quality of life and sleep, studies on defining quality of life has increased in recent years. There are many studies stating that pain is associated with perceived quality of life. ${ }^{[15,16]}$ In Turkey, there are studies on patients having chronic pain but none are specific to pain clinics. The purpose of the study was to determine the relationship between pain perceived by the patients hospitalized in the algology clinic and their sleep and quality of life.

\section{Materials and Methods}

\section{Population and sample}

Of the inpatients treated in the algology clinic of a university hospital in the city center of Sivas, those who were over 18 years of age and agreed to participate in the study comprised the study population. The study was conducted between January 2011 and December 2011. After the power analysis, the values were set as $\alpha=0.05, \beta=0.20,(1-\beta)=0.80$ and it was decided to include 122 patients in the sample. The power of the test was assessed as $\mathrm{p}=0.89904$.

\section{Data collection tools}

Data were collected through Personal Information Form, Visual Analog Scale (VAS), Pittsburg Sleep Quality Index (PSQI) and Short Form 36.

Personal Information Form: Personal Information Form was composed of 20 questions on socio-demographic features and diseases of the patients.

Visual Analog Scale (VAS): VAS scale used in evaluating the severity of pain was developed by Price et al. Response is indicated along a $10 \mathrm{~cm}$ continuum where $0=$ no pain and $10=$ severe pain. In the said scale, patients mark the line at the point that best represents the severity of their pain. Then, the distance between the mark and the lower end is mea- 
sured in $\mathrm{cm}$ and the obtained numeric value indicates the severity of the pain. ${ }^{[17]}$

Pittsburg Sleep Quality Index (PSQI): PSQI, which is a self-rated questionnaire assessing sleep quality and sleep disturbance over one-month period, was developed by Buysse et al. in 1989. PSQI has 19 questions grouped into 7 component scores, each of of which has a range of $0-3$ points. The seven component scores are added to yield one global PSQI score. Global score ranges between $0-21$ where $\leq 5$ indicates "good sleep and $>5$ indicates "poor sleep". Validity and reliability of PSQI in Turkey were carried out by Agargun et al. (1996) and Cronbach's alpha internal consistency coefficient was found to be $0.80 .^{[4,18]}$ In the present study Cronbach alpha coefficient was found to be 77 .

Short Form 36 (SF-36): Short From 36, which is a self-administered, 36 item questionnaire developed by Ware and Sherbourne (1992), was translated into Turkish by Kocyigit et al (1999) who also carried out validity and reliability studies. SF-36 comprises 8 dimensions: Physical Functioning (10 items), Social Functioning (2 items), Role-Physical (4 items), Role-Emotional (3 items), Mental Health (5 items), Energy/Vitality (4 items), Pain (2 items), General health (5 items). SF-36 is evaluated for recall over the last four weeks. Dimensions are scored between 0 and 100 where the maximum score indicates a good health. ${ }^{[19,20]}$ In our study, Cronbach alpha coefficient was found to be 91 .

\section{Process}

Data collection tools which consist of characteristics of patients and accepting to participate in the study were administered during face-to-face interviews. Forms were completed in approximately 1520 minutes.

\section{Ethical principles of the study}

Before starting the study, an approval was obtained from Cumhuriyet University Health Research and Training Hospital Ethical Committee (Decision no: 2010-03/15) and from the hospital where the study was undertaken. The aim of the study was conveyed to those accepting to participate in the study, consents were obtained and the study was conducted according to the Helsinki Declaration.

\section{Statistical evaluation}

Data were evaluated using SPSS 14.00 package program. T-test, Kruskal-Wallis test and Mann-Whitney $U$ test were employed in comparison of descriptive features, quality of sleep and life and pain while quality of sleep, quality of life and VAS were compared using pearson correlation. Significance level was taken as $\mathrm{p}<0.05$.

\section{Results}

\section{Descriptive features}

In the present study, average age was $50.8 \pm 13.8$ and there were $79(64.8 \%)$ women. $100(82 \%)$ of the individuals were married, $46(37.7 \%)$ were primary school graduates and 64 (52.5\%) were housewive. When perceived income was questioned, 84 individuals stated that their income was equal to their expenses. Nearly all (99.2\%) had a social security. The distribution of the length of stay in hospital was $1.2 \pm 1.1$ days. $94(77.0 \%)$ of the participants had no attendant, $9(73.0 \%)$ had a history of hospitalization and $30(24.6 \%)$ had undergone a surgery. 90 $(73.8 \%)$ of the patients had chronic condition related with nerve system in 35 (28.7\%), musculoskeletal system in $29(23.8 \%)$ and cardiovascular system in $25(20.5 \%)$ patients. Mental diseases $(0.8 \%)$ and respiratory system diseases (0.8), followed by cancer $(2.5 \%)$ were the most rare conditions observed. $63(51.6 \%)$ of the patients perceived their health as moderate while $64(81 \%)$ of those reporting health problems were women and $76(62.3 \%)$ were living with their spouses and children.

\section{Findings related to pain and the quality of sleep and life}

Average VAS score was $6.9 \pm 2.5$, total PSQI score was $10.0 \pm 4.5$ and $85.24 \%$ of the patients had poor sleep ( $>5)$. In terms of SF-36 dimensions, average Physical Functioning was found to be $36.3 \pm 26.7$, Role-Physical as $19.8 \pm 32.1$, Pain as $66.0 \pm 22.3$, General Health as $51.2 \pm 12.7$, Vitality as $51.7 \pm 13.6$, Social Functionality as $43.6 \pm 16.1$, Role-Emotional as 19.6 \pm 38.9 and Mental Health as $50.4 \pm 13.8$.

\section{Comparison of descriptive features, quality of sleep and life and pain}

Table 1 shows average scores of quality of sleep, quality of life and VAS with reference to the descriptive 


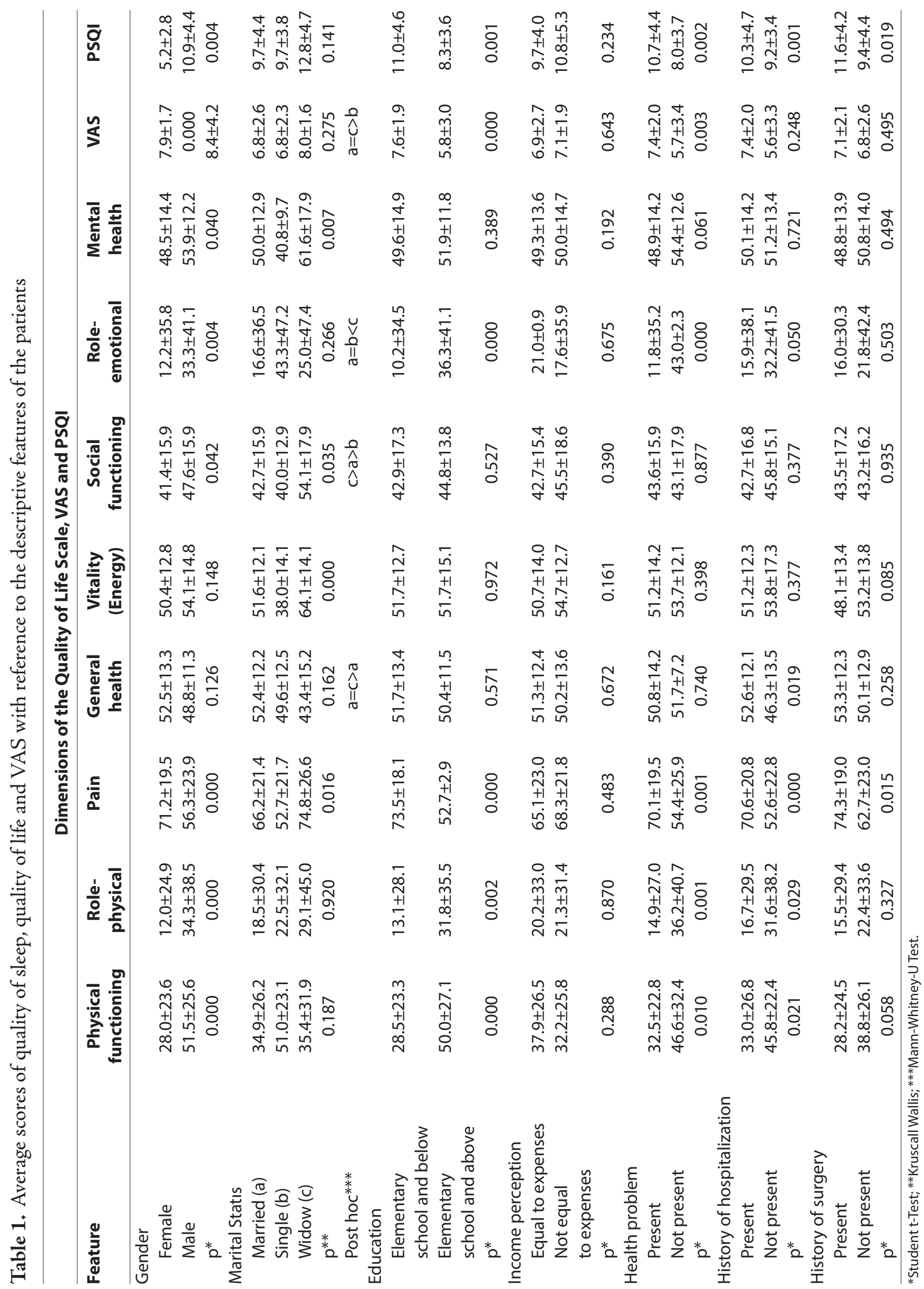


features of the patients. When quality of life (QoL) dimensions are examined, Physical Functioning, Role-Physical, Social Functioning, Role-Emotional and Mental Health scores were found to be better in men and in those having no health problems when compared to women and to those having no health problems, respectively. Pain, which is another dimension of QoL, was found to be higher in women than men, in marrieds and widows than singles and in those having a health problem than those having no health problem. Energy was found to be the lowest in singles, followed by marrieds and widows. Social functioning was better in widows than marrieds and singles. Mental health was lower in singles than marrieds and widows. Comparison of VAS and PSQI revealed that VAS and PSQI scores were worse in women than men and in those having health problem than those having no health problem.

\section{Findings related to comparison of quality of sleep, quality of life and VAS}

Table 2 shows the relation of quality of sleep, quality of life and VAS. A moderate negative correlation was found between VAS and three dimensions of SF-36, namely Physical Functioning ( $\mathrm{r}=-0.478 ; \mathrm{p}=0.000)$, Role-Physical ( $\mathrm{r}=-0.416$; $\mathrm{p}=0.000)$ and Role-Emotional $(r=-0.389 ; p=0.000)$. VAS was weakly and negatively correlated to Vitality $(\mathrm{r}=-0.138 ; \mathrm{p}=0.158)$ and Mental Health $(r=-0.217 ; p=0.024)$. There was a good linear correlation between VAS and QoL pain score $(\mathrm{r}=0.606 ; \mathrm{p}=0.000)$ while there was a moderate linear correlation between VAS and the total sleep score $(r=0.425 ; \mathrm{p}=0.000)$. A moderate negative correlation was found between Sleep Quality Index and three dimensions of SF-36, namely Physical Functioning $(r=-0.310 ; \mathrm{p}=0.000)$,

Role-Physical ( $\mathrm{r}=-0.203 ; \mathrm{p}=0.023)$ and Role-Emotional $(\mathrm{r}=-0.180 ; \mathrm{p}=0.035)$. It was found that quality of life was not statistically significanty correlated to General Health and Social Functioning ( $r=0.001$, $\mathrm{p}=0.765 ; \mathrm{r}=0.084 ; \mathrm{p}=0.307$, respectively).

A statistically significant correlation was found between VAS and PSQI $(r=0.425 ; \mathrm{p}=0.000)$.

\section{Discussion}

In the present study where the impacts of the pain perceived by patients hospitalized at the pain clinic on the quality of sleep and life were studied, it was found that quality of sleep and quality of life were influenced negatively. Results obtained are discussed herein under two headings as:

1- Descriptive features and findings related to quality of sleep-life and pain

2- Correlation of VAS to quality of sleep and quality of life

\section{Descriptive features and findings on quality of sleep-life and pain}

Our study is similar to previous studies in that Physical Functioning, Role-Physical, Role-Emotional and Social and Mental Health dimensions of QoL were better in males. ${ }^{[21-25]}$ Thomtén et al. ${ }^{[16]}$ found that long-term pain affected general health, social and psychological well-being negatively. Having a better quality of life in men can be related to the facts that women have more responsibility in daily life, have more chronic diseases and higher reaction, perception and sensitivity towards events.

This could also be related to other factors such as doing houseworks is most of the times perceived as the natural responsibility of women, most of the women does not have a regular income, have limited access to different social environments and roles and have insufficient social support. Studies conducted have reported that a better quality of life in men are related with genetic, hormonal, anatomic, biological, mental, socio-cultural and lifestyle differences. ${ }^{[26]}$

It was found in the present study that VAS and PSQI scores were worse in women and those having health problems. In women, pain and poor quality of sleep may be associated with the facts that women are more sensitive to pain-sleep problems and their responsibilities, are away from their houses at hospital and are better in defining their pain and seeking help in health related issues. Epidemiological studies have shown that women report more intense and frequent pain than men. ${ }^{[26]}$ However, in a study on young adults, Graham and Streitel ${ }^{[5]}$ found that gender was not associated with quality of life and pain, which is not consistent with our result.

In the present study, pain scores were found to be were higher in females, married individuals and 


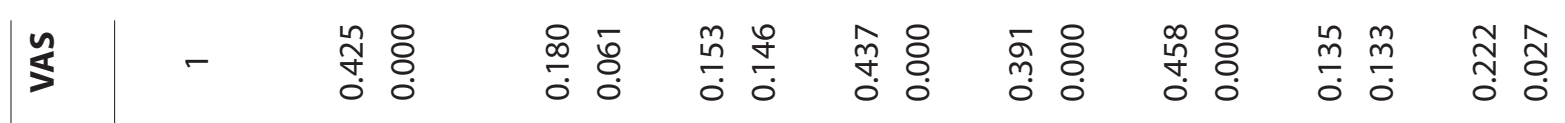

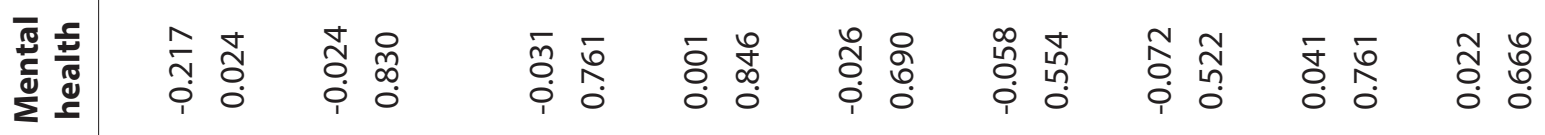

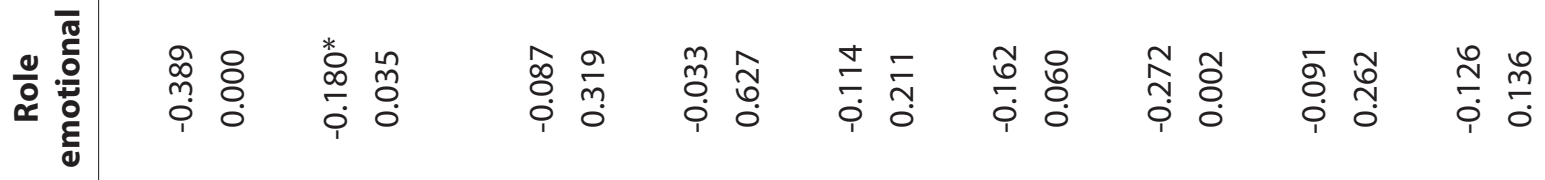

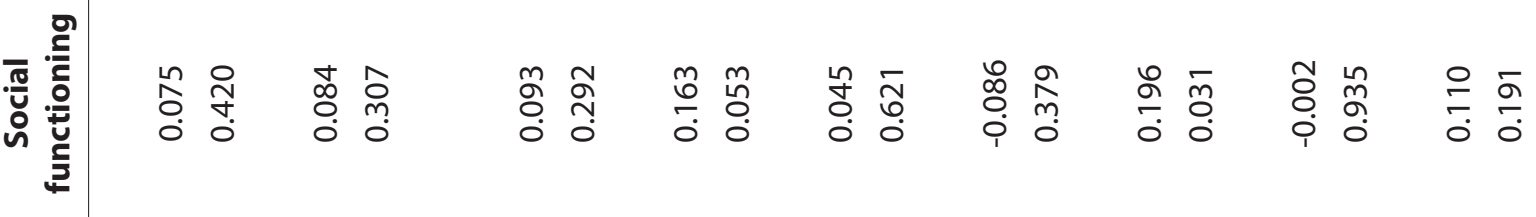

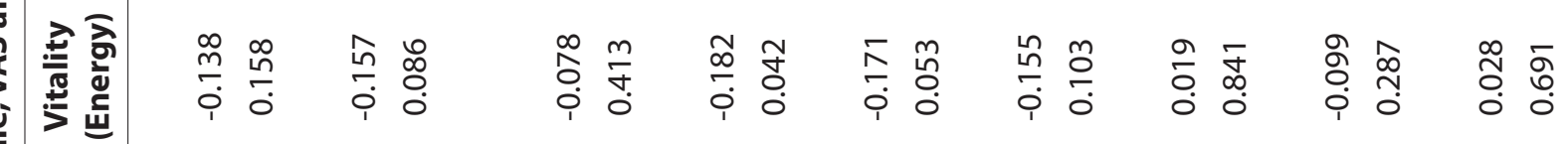
芉

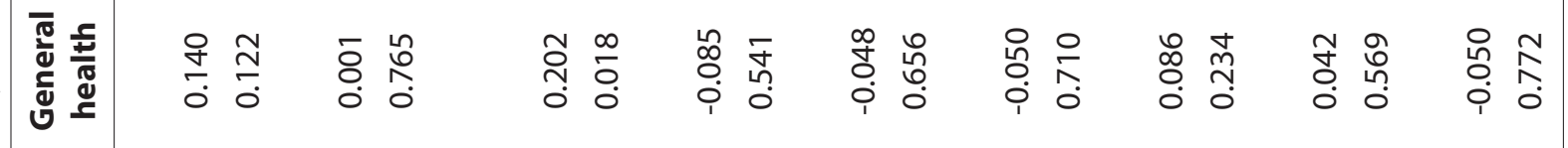

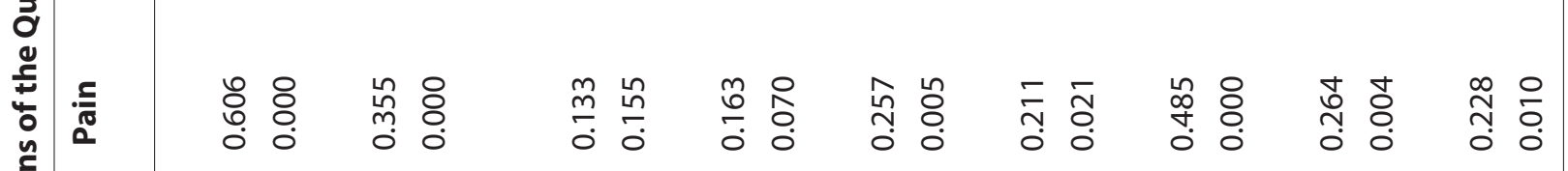

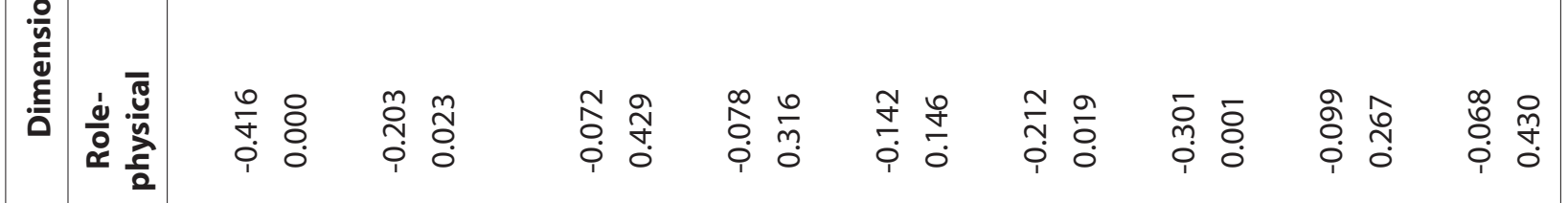

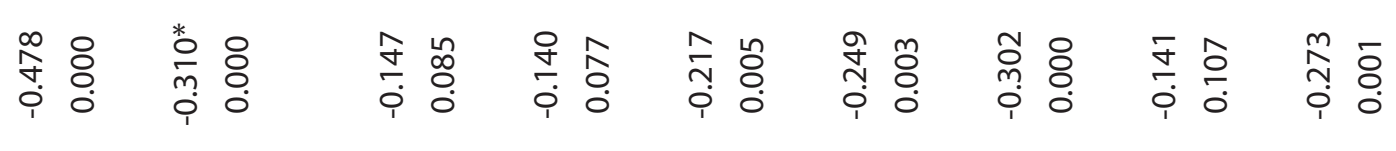


those having health problems. In a study conducted on patients having chronic low back pain, Dündar et al. $^{[27]}$ found no relation between marital status and quality of life. Ordu Gokkaya et al. ${ }^{[21]}$ evaluated pain and quality of life in 275 elderly patients and found that there was no association between marital status and the quality of life, which was not consistent with our findings. These different findings could be related with having an older patient group $(72.77 \pm 5.7)$ in Ordu Gokkaya et al.'s ${ }^{[21]}$ study and younger patient group $(34,4 \pm 10,4)$ in Dündar et al.'s ${ }^{[27]}$ study when compared to our patient group.

\section{Findings related to the correlation of quality of sleep, quality of life and VAS}

As the level of pain increases, scores on dimensions of QoL, namely Physical Functioning, Role-Physical and Role-Emotional decrease and scores of pain increase. In the literature, people having pain have reported experiencing difficulties in maintaining their physical, occupational and daily activities, feeling less energetic and having problems in attending social activities and coping with mental issues. ${ }^{[22]}$ Ordu Gokkaya et al. ${ }^{[21]}$ conducted a study on 275 patients and found that nearly all the patients had pain and there was a relation between pain and low quality of life. Becker et al. ${ }^{[28]}$ found that pain was correlated with Physical Functioning dimension of QoL.

In a study on palliative care patients, Boström et al. ${ }^{[29]}$ found the scores for the quality of life dimensions physical functioning, role-physical and bodily pain were significantly different in patients. In patients having chronic back pain, Dündar et al. ${ }^{[27]}$ found that Role-Physical dimension of SF-26 was negatively and closely associated with bodily pain while Physical Functioning, General Health and Social Functioning dimensions were negatively correlated. In studies similar to our study, it has been found that pain affects quality of life in every field. ${ }^{[22,24]}$

In our study, it was found that quality of life worsened as the pain level increased. Pain and sleep problems are among the most important health issues. In the literature, patients having pain have been reported to wake up frequently, experience difficulties in falling asleep and maintaining sleep, spend more time in bed asleep and have poor sleep quality due to sleeping less. ${ }^{[10,15]}$ Previous studies have reported that half of those patients reporting least level of pain had sleep problems. ${ }^{[5,6,30]}$ Sayar et al. ${ }^{[31]}$ conducted a study on 40 healthy individuals and 40 chronic pain patients and found that quality of sleep decreased as the intensity and level of pain increased. In a study conducted on patients having chronic pain, Lunde et al. ${ }^{[32]}$ found that chronic pain was correlated with poor sleep quality, which led to problems such as difficulty in initating and maintaining sleep and impairment in daytime functioning. Our results are parallel to the results obtained in previous studies. ${ }^{[9,33,34]}$

In the present study, a significant moderate negative correlation was found between quality of life and the dimensions of QoL: Physical Functioning, Role-Physical and Role-Emotional. Quality of life decreases as the quality of sleep worsens. In a study on cancer patients, Mystakidou et al. ${ }^{[15]}$ found a significant negative relation between poor quality of sleep and physical and emotional dimensions of QoL, which is parallel to our results. Many other studies support these results too. ${ }^{[35,36]}$

In conclusion of study, quality of sleep and life was found to decrease as the level of pain increased and quality of life was affected negatively when the quality of sleep was poor. Applications towards resolving pain would have a positive affect on the quality of sleep and life. Health professionals at pain clinics need to know the causes, features and prevalence of pain along with effective factors and approaches towards resolving pain. In this regard, they may contribute to early recovery by reducing pain perception, which would contribute to quality of sleep and life. Moreover, it is recommended to evaluate quality of sleep and quality of life and plan appropriate interventions in patients hospitalized at pain clinics. Further studies on larger populations are also recommended.

\section{Limitations of the study}

Conclusions of the present study cannot be generalized beyond the study group.

\section{Conflict-of-interest issues regarding the author- ship or article: None declared.}

Peer-rewiew: Externally peer-reviewed. 


\section{References}

1. Pirbudak Çöçelli L, Bacaksız BD, Ovayolu N. The nurse factor in pain therapy. Gaziantep Medical Journal 2008;14(1):53-8.

2. Berker $E$, Dinçer N. Chronic pain and rehabilitation. Agri. 2005 Apr;17(2):10-6.

3. Kuzeyli Yildirim Y, Uyar M, Fadillioğlu C. Cancer pain and its influence on quality of life. Agri 2005;17(4):17-22.

4. Ağargün MY, Kara $\mathrm{H}$, Anlar Ö. The reliability and validity of the Pittsburgh Sleep Quality Index. Turkish Journal of Psychiatry 1996;7(2):107-15.

5. Graham JE, Streitel KL. Sleep quality and acute pain severity among young adults with and without chronic pain: the role of biobehavioral factors. J Behav Med 2010;33(5):335-45.

6. Smith MT, Perlis ML, Smith MS, Giles DE, Carmody TP. Sleep quality and presleep arousal in chronic pain. J Behav Med 2000;23(1):1-13. CrossRef

7. Chapman JB, Lehman CL, Elliott J, Clark JD. Sleep quality and the role of sleep medications for veterans with chronic pain. Pain Med 2006;7(2):105-14. CrossRef

8. Cunningham JM, Blake C, Power CK, O'Keeffe D, Kelly V, Horan $\mathrm{S}$, et al. The impact on sleep of a multidisciplinary cognitive behavioural pain management programme: a pilot study. BMC Musculoskelet Disord 2011;12:5. CrossRef

9. Marty M, Rozenberg S, Duplan B, Thomas P, Duquesnoy B, Allaert F. Quality of sleep in patients with chronic low back pain: a case-control study. Eur Spine J 2008;17(6):839-44.

10. Blågestad T, Pallesen $S$, Lunde LH, Sivertsen B, Nordhus IH, Grønli J. Sleep in older chronic pain patients: a comparative polysomnographic study. Clin J Pain 2012;28(4):277-83. CrossRef

11. Günvar T. Basic principles of chronic pain management in primary care. TJFMPC 2009;3(3):14-7.

12. Skevington SM, Lotfy M, O'Connell KA; WHOQOL Group. The World Health Organization's WHOQOL-BREF quality of life assessment: psychometric properties and results of the international field trial. A report from the WHOQOL group. Qual Life Res 2004;13(2):299-310. CrossRef

13. Eti Aslan F. Pain assessment methods. Cumhuriyet University Journal of Nursing High School 2002;6(1):9-16.

14. Berk HO, Bahadir G. The experience of chronic pain and pain beliefs. Agri 2007;19(4):5-15.

15. Mystakidou K, Parpa E, Tsilika E, Gennatas C, Galanos A, Vlahos L. How is sleep quality affected by the psychological and symptom distress of advanced cancer patients? Palliat Med 2009;23(1):46-53. CrossRef

16. Thomtén J, Soares JJ, Sundin Ö. The influence of psychosocial factors on quality of life among women with pain: a prospective study in Sweden. Qual Life Res 2011;20(8):1215-25.

17. Price DD, McGrath PA, Rafii A, Buckingham B. The validation of visual analogue scales as ratio scale measures for chronic and experimental pain. Pain 1983;17(1):45-56. CrossRef

18 Buysse DJ, Reynolds CF 3rd, Monk TH, Berman SR, Kupfer DJ. The Pittsburgh Sleep Quality Index: a new instrument for psychiatric practice and research. Psychiatry Res 1989;28(2):193213. CrossRef
19. Ware JE Jr, Sherbourne CD. The MOS 36-item short-form health survey (SF-36). I. Conceptual framework and item selection. Med Care 1992;30(6):473-83. CrossRef

20. Koçyiğit H, Aydemir Ö, Ölmez N, Memiş A. Kısa Form-36 (SF36)'nın Türkçe versiyonunun güvenilirliği ve geçerliliği. İlaç ve Tedavi Dergisi 1999;12(2):102-6.

21. Ordu Gokkaya NK, Gokce-Kutsal Y, Borman P, Ceceli E, Dogan A, Eyigor S, et al. Pain and quality of life (QoL) in elderly: the Turkish experience. Arch Gerontol Geriatr 2012;55(2):357-62.

22. Yazııı K, Tot Ş, Biçer A, Yazıcı A, Buturak V. Anxiety, depression and quality of life in patients with lowback pain and neck pair. [Article in Turkish] Clinic Psychiatry 2003;6(1):95-101.

23. Arslantaş D, Metintaş S, Ünsal A, Kalyoncu C. The quality of life in the elderly people of mahmudiye township of Eskişehir. Osmangazi Medical Journal 2006;28(2):81-9.

24. Jakobsson U, Hallberg IR, Westergren A. Overall and health related quality of life among the oldest old in pain. Qual Life Res 2004;13(1):125-36. CrossRef

25. Gerdle B, Björk J, Henriksson C, Bengtsson A. Prevalence of current and chronic pain and their influences upon work and healthcare-seeking: a population study. J Rheumatol 2004;31(7):1399-406.

26. Şahin Ş. Gender and pain. Pain 2004;16(2):17-24.

27. Dündar Ü, Solak Ö, Demirdal ÜS, Toktaş H, Kavuncu V. Relation of pain, disability and depression with quality of life in patients with chronic low back pain. General Medical Journal 2009;19(3):99-104.

28. Becker N, Thomsen AB, Olsen AK, Sjøgren P, Bech P, Eriksen J. Pain epidemiology and health related quality of life in chronic non-malignant pain patients referred to a Danish multidisciplinary pain center. Pain 1997;73:393-400. CrossRef

29. Boström B, Hinic $H$, Lundberg D, Fridlund B. Pain and healthrelated quality of life among cancer patients in final stage of life: a comparison between two palliative care teams. J Nurs Manag 2003;11(3):189-96. CrossRef

30. Swann J. Why your approach to pain affects quality of life. Nursing and Residential Care 2010;12(10):487-90. CrossRef

31. Sayar K, Arikan M, Yontem T. Sleep quality in chronic pain patients. Can J Psychiatry 2002;47(9):844-8.

32. Lunde LH, Pallesen S, Krangnes L, Nordhus IH. Characteristics of sleep in older persons with chronic pain: a study based on actigraphy and self-reporting. Clin J Pain 2010;26(2):132-7.

33. Marin R, Cyhan T, Miklos W. Sleep disturbance in patients with chronic low back pain. Am J Phys Med Rehabil 2006;85(5):430-5. CrossRef

34. van de Water AT, Eadie J, Hurley DA. Investigation of sleep disturbance in chronic low back pain: an age- and gendermatched case-control study over a 7-night period. Man Ther 2011;16(6):550-6. CrossRef

35. Katz DA, McHorney CA. The relationship between insomnia and health-related quality of life in patients with chronic illness. J Fam Pract 2002;51(3):229-35.

36. Veldhuijzen DS, Greenspan JD, Smith MT. Sleep and quality of life in chronic pain. Sleep and Quality of Life in Clinical Medicine 2008:187-97. CrossRef 